$$
\begin{aligned}
& \mathbf{T} \mathbf{T} \\
& 894 \\
& . \mathrm{H} 4
\end{aligned}
$$

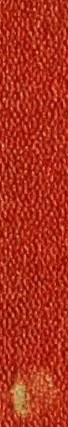




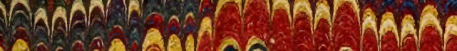

MMM M MMA A

nân

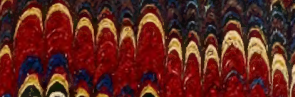

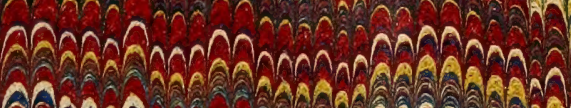
a nM 6 Mancher zon CMna A Cun

Ar)

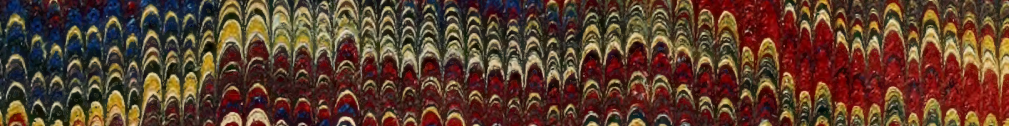

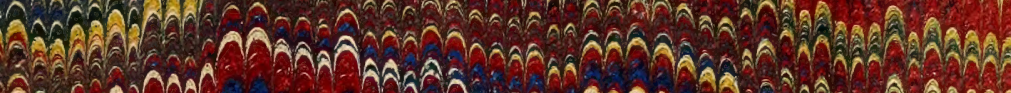
A

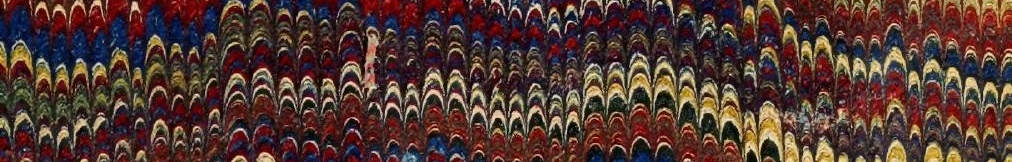

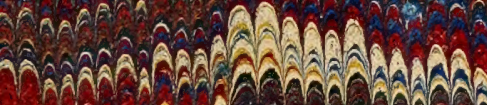

A

a

A

â,

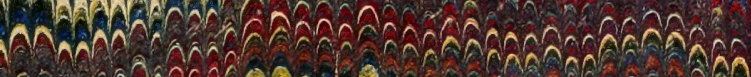









\section{INSTR UCTIONS}

IN
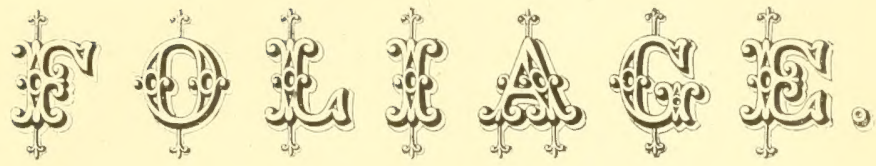

IN TWO PARTS.

\section{IHAD.ANE HERTMEN.}

PRICE, \$3.00.

'This Book can be had from the Author, at No. 113 West Forty-First Street, New York. 
U 
Entered according to Art of (ongress, in the year 1573. by

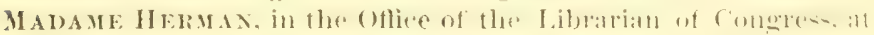
Washington. D. C 


\section{COONENTS. \\ OF}

PAR'T I.

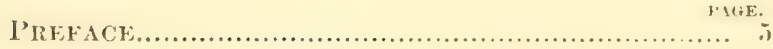

Chapter I.-Materials used for Making Foliage..... 7

II.-Coloring of the Wax .................. 9

. $\quad$ III.-General Instructions ................... 12

.. IV.-Steming and arranging of Plantw..... 15 


\section{P R E F A C E.}

This beautiful art of which I am thankful to Providence to be the inventor, has been taught by me in New lork with great success, in fact it has been pronounced the yportest invention of the day.

Its great merit lies in its simplicity-no moulds nor $\therefore \cdot 1$ : sors being userl-every leaf in wax being made from th, natural leaf; and the greatest exartness and perfertion. every filser, indenture, contomr and oven defert which are on the natural plants are so well imitated that it is alumst impersihle to know, unless by the touch, that it is mely wax.

Not any knowledge of painting or coloring is necen-ary, the color's heing mixed in the wax, the different shatre of "olor's being easily obtained to imitate to sreat perfection the tints of all plants, thus ropying the book of nature.

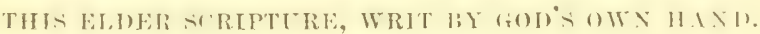

Modelling in Wax is an art of erreat antipuity, combining

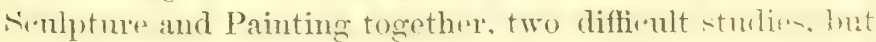
whirh an here rendered easy by the very plastic nature of the materials used, which will yield well to the will of the moleller who will he able to give that appearanes of rality or life which constitutes the trur poetry of art.

'The anthor indulges the hope that this art will uot only afford gratifieation to those who will learn the method from this hook, as it has done to those I have hat the pleasure of teaching, but will also be useful by preserving such lifelike portraits of all plants which may he viluatble to lovers of Botany and to all who love nature. 
Thas present bouk, as the hook of Instruction in Wax Flowers, has been composed more fartirularly to supply the want of persoms living at al listanee and who wan not come to this city to learn this art.

I shall be glad at any time to veceive any ome who wonkd likes to have any explanation concerning this methorl. 


\section{PLATE I.}

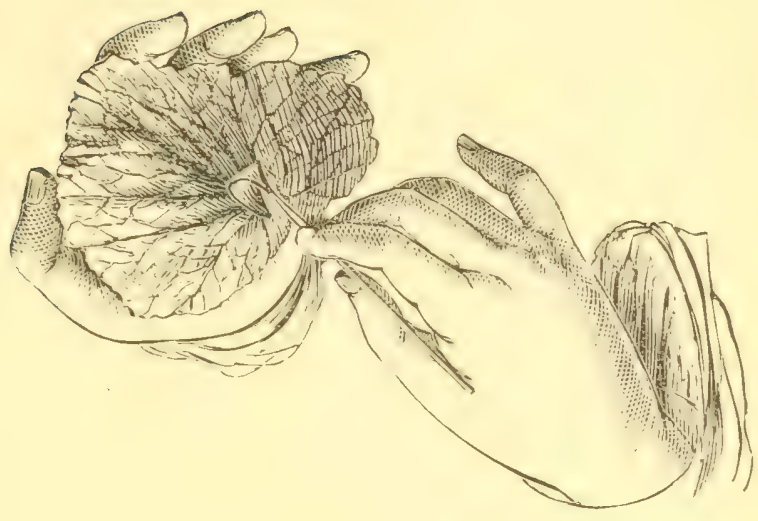

PLATE II.

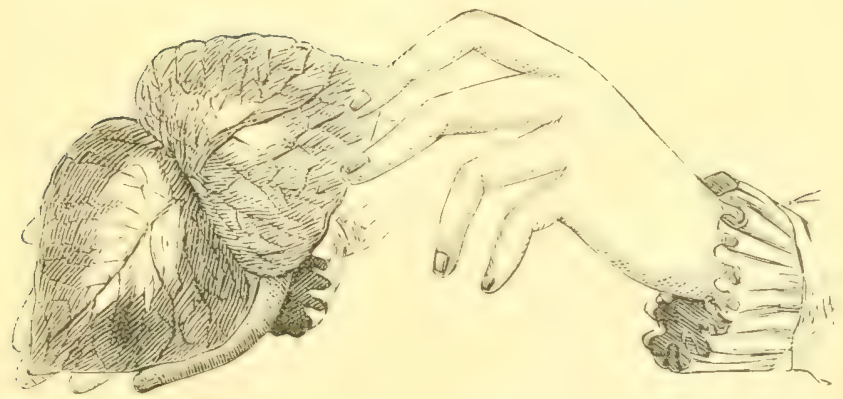





\section{(YHAP'IER I.}

MATERIAL FOR ILIKLYT FOLIARE.

A lampl with two bumer's is neressary to melt two rups of wax at a time. Aleohol is the hest liquid to nse as it is free from smell and is comparatively safe.

Five or six tin enps, onsting five "ents eath, and which "an be hat from any tin shop, alre also wanterl.

One pound of the best cake wax.

$\Lambda$ few tubes of oil paints of different colors.

One spool wire for stems of small leaves.

(One coil wire for stems of large leaves and plants.

A hottle of moneilage : as a good puantity of this is regluired. I hase fomml it cheaper to buy one pound of Arahis ymm and make the moneilage myself by mixing some grum in cold watere, it is not necessary to have the mneilage very thick.

A few hottles of French down or Flork of sifferent rolors a)e also wanted.

A stomp brush to finish the plants.

Half a dozen of ('amel's hair brushes to dip in the cups of wax. As the hrushes are lather short. a piece of wood trimmerl with a knife and inserted into rach hrush will give the desired length.

A small quantity of glycerine is also required.

All the abore named articles, except the alcohol, the tin cups, the mucilage and the glycerine an be had from me 
at a nuch smaller price tham eould he hal form any other place.

The great quantity of materials that I am obliger to have always on hamd to supply the demamd of all my pmpils, and also my knowledge of the best puality of all these articles, enables me to defy competition.

A look at my juine list companerl with any othere will soon show the difference. 


\section{CHAP'TER II.}

(O) ORINT OH THE W.L.

'This buaneh of the methorl beinge the most inportant. propere are shomld be talken to imitate ats well at possible the different color's of the natural plants.

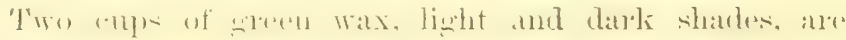
necessistry.

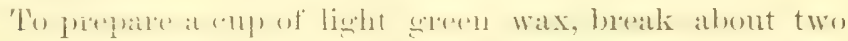

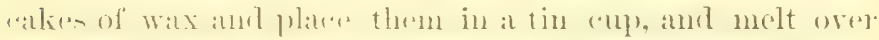
the lamp: then take the tuhe of theme Green, Xo. 1.

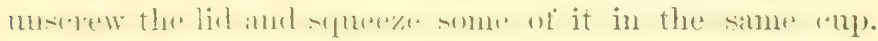

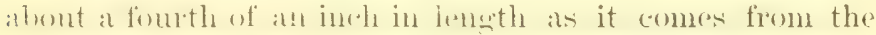
thlu : mix it wedl in stiring it with a camel's hatir hrush.

When all the wax is metted in the ren, it is rearly for

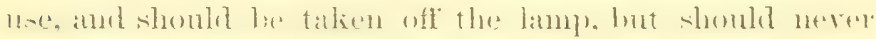
be allowed to boil, as it spoils it.

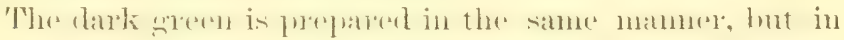
using Chrome Green No. 2, , in same quantity.

Mixing ('home limen. No, :), and ('hrome Lellow in

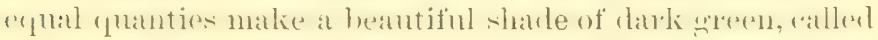
moss yieen.

If a soft yellow green be wanted. at dor geranium leatren.

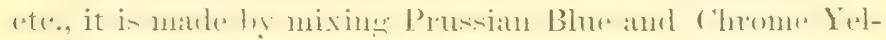

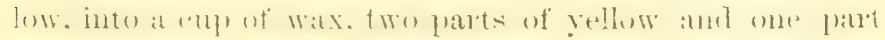
of blue.

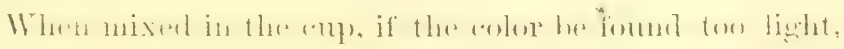
and some more color to it. 
Adding white cake wax to any coloresl reup reslures the said color:

Put with two cakes of wax a mall quantity of silver white in a tin cup, and you will have a '"up of wax beantifully white.

If the white wanted has a little tinge of yollow in it, anli a very small quantity of Chrome Yellow to the silver white.

A very little quantity of ('hrome Green, No. 1, to ahont three times as much of silver white will sometimess be wanted to imitate some leaves.

A nice gray color which is observalule in some plants can be imitated by mixing a very small quantity of Irory Black with twice ats much of silver white in a colp of wax.

A cup of camine is desirable, ats it is often $11-\mathrm{d}$; a

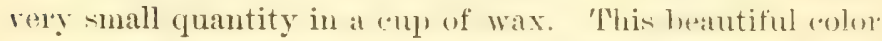
is also used to grive the last touch te the platuts, to conion th. reins and edger, and if mixed with Bown pailit will give a rich appearance to many leaves.

Many leaves, and particularly the antmm leaves an partly yellow, which can be initated with chome lellow in white wax, or sometimem (1)imge ('hrome. A look at the different rolors will soon show what is wanted.

When your eup of white wax beromes dirty, pour it in al cup of green wax while it is hot.

'l'he best way of "leaming a $1 \cdot 11$ ) in with soft papere while it is warm.

You (an alan mix the yellow wax with greese, if you reequire an empty cup to melt something else.

Never waste any wax, as it can always be used.

Always keep) your (mp rovered or turned over when not in use, to keep the colors fresh.

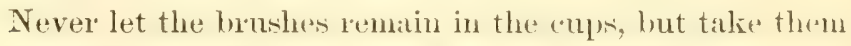
sut before the wax grets rolk. Do not attempt to pull at brush from the wax when it is set. 
A little practioe will som give the sturlent the idea of mixing the aolors which are suitable to the plants.

If not surecessful in the first attempt try again, for as Shakspeare says:

* What is worth doing at all

[s wortl doing well:" 


\section{CHAP'IER III.}

GEYTRAT INSTRUOTIONS.

e ne Foliage leving mate fiom the nat ural leat, it is necessary to have a few natural leaves to work from. We will suppose that the stulent has a Bempon $R+x$ plant, which "an be easily procmed, and which is rery easy to make.

'The student will peroreive that this leaf is composed of

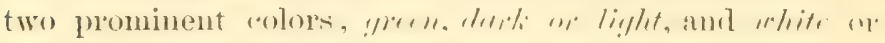
"frey, or of a yreenish white.

Let it remain in rold watel for a few minntw while vom

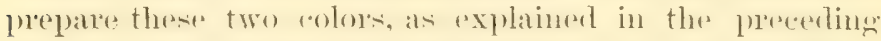
('hapter: the student will them place the natural leaf' in the left haml. with the emom! side "1, which is the hatek of the loaf, and where all the veins ane most romsplenoms. Ifaving "nt the stem rome to the leaf, the next thing is to

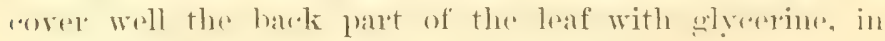
spreating it with a small, camel's hair brush.

'Then taking the where or !fer!y hot was from the lampl,

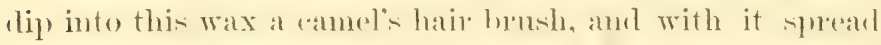
the wax oree the ele pere pert of the leate. thes eorering with white wax all the white part of the leaf. A look at Plate I will show how to hold the leaf in the loft hand and the way of using the camel's hair brush.

When all the white pate of the leat is well coreserl with white wax, the student will then eover the rest of the leat with neen hot wax, spenealing it well with the eamel's hate brush over the whole hack of the leat, that is to say, that the gleen part of the leaf must he covered with green wax, 


\section{PLATE III.}

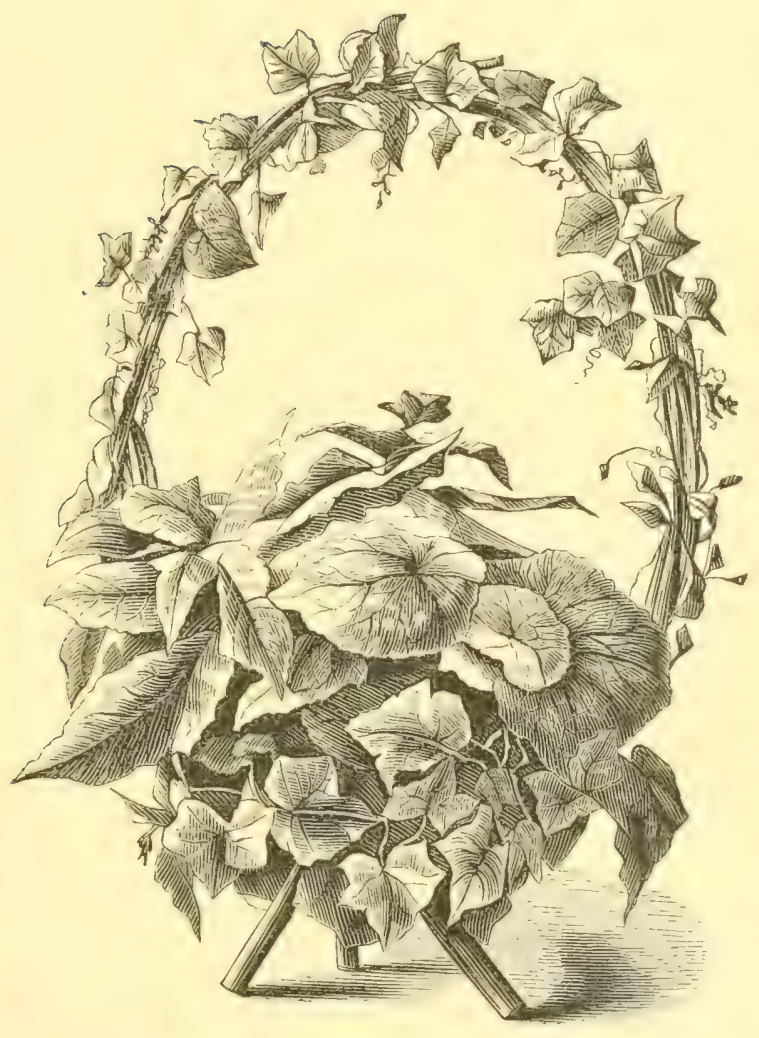



and the white wax which is alleally on the leaf must also he

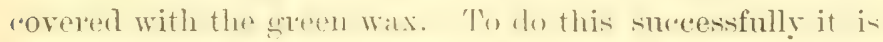
hest to begin to speread the wax firet from that part of the leaf where the strm was. in following the lawesest voin to

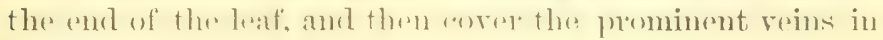
that manner:

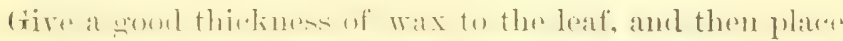

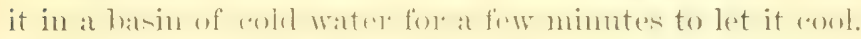

'Taking it ont of the water. yon plate it in your le ft hamel

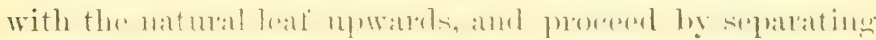

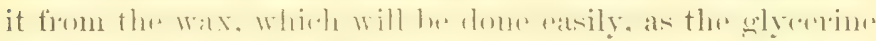

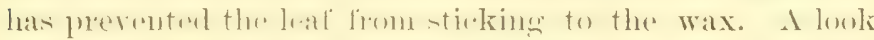

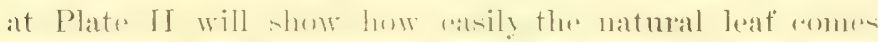
apart fiom the wax leaf.

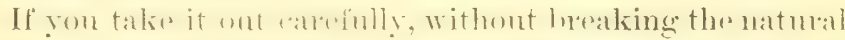

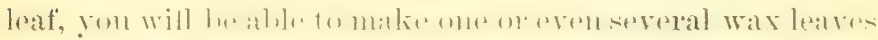
from it.

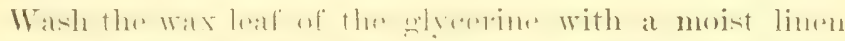

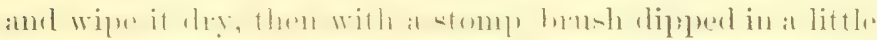

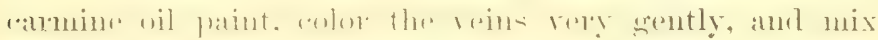

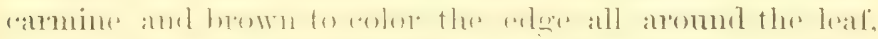
and it will the tini-hed with the axention of the steminge. which is explained in the following chapter.

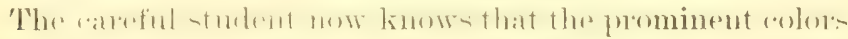

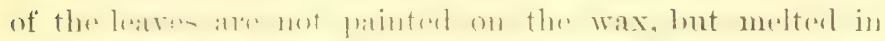

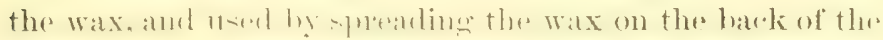

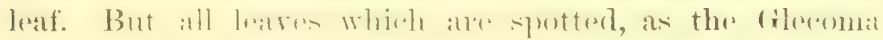

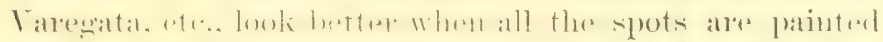

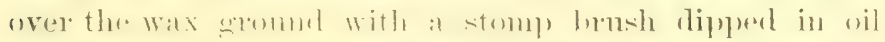
paint.

I will now take a coleus leaf to explain the way of making the beautiful downy or velvety leaves.

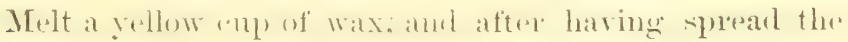
grycerine orege the bate of the leaf. rover the whole hack of the leat with the wellow wax: then put it in a hasin of 
cold water" to let it rool: taking it ont of the water, and separating the natural leaf from the wax, the wax leaf will then be all yellow: the leaf will penpire now hat the down me velvet, which is put on in this way : spreat some murilage with a small brush orere the wax leaf. hut leaving the

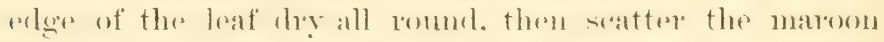

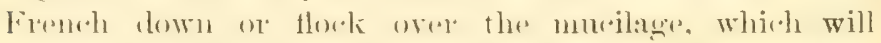
then athere to it, then turn the leaf overe, so as to shake off the extra down. Wash the estge or margin with at moist linen to have the leaf yellow all rome and the lest with the relvet on it.

In winter. I would recommend the pupil to put into each "up of melted wax half a teaspoonfull of larth oil to soften the wax. 


\section{CHAP'IER IV.}

STEMING ANI) ARRANGLNG OF PLANTS.

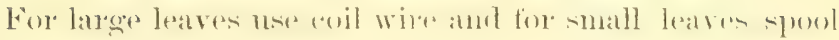
wire.

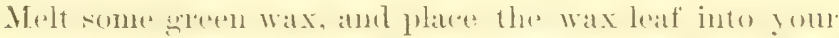
left hatur, with the hatele of the leat upward amb the

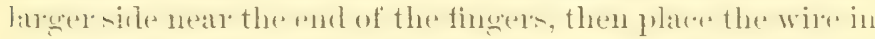
the centere or ritgere of the leate, not on one siele. and let it

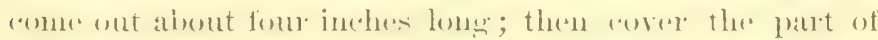

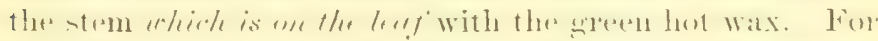

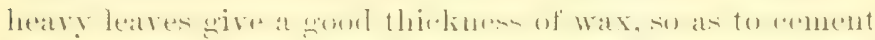

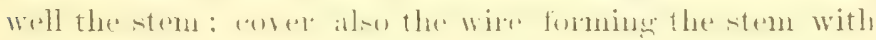
green wax.

All whety leares -hould he-semed hefore putting the down over them.

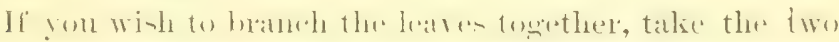

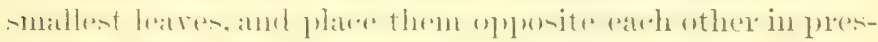
-ing the ton stems together ar twistiug them togethere: then the two mext leaves in -ize. in putting then lower down undere the two first leares. The best way to do this

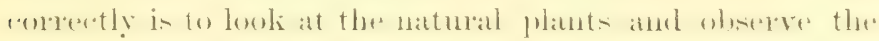
way the leaves ane put together. I would request the

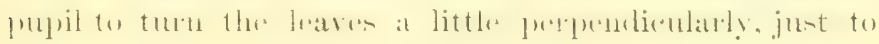
show but the right siele of the leatres.

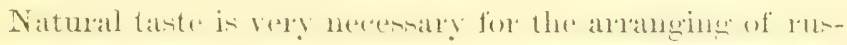

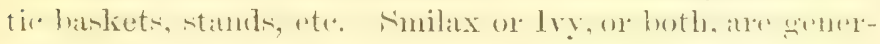

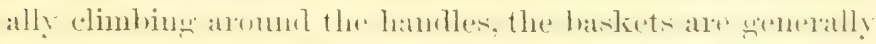

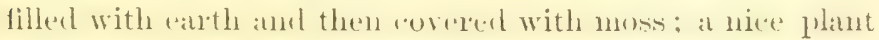
of Begronia Rex may le plared in it in stickinge the stems 
hrought together into the rarth of the basket. Put a few of the plants, as Colens in front of the hasket, and geraniums or other plants. A spray of Forn leaven look- also very well.

Plate III shows a hasket of foliager that I maln. amel which has been much atmixed.

I -hall be very happy to give to any ome an! "xplamation which would not be enenerally mulerstom ly 1 my Book of Instruction.

The following is at list of the phant which ate the most

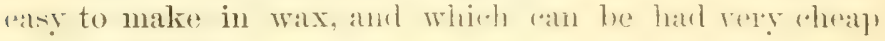
from any florist.

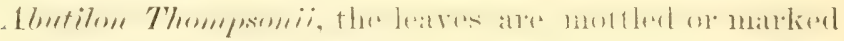
with bright golden yellow.

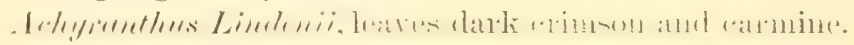
Aucuba oreponice.

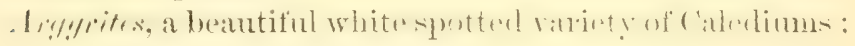
one of the smallest kinds growing.

Artemisie Stelleris, foliage of a silver gray lane.

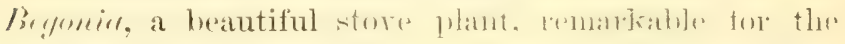
variect and magnificent foliage of many of it valetion:

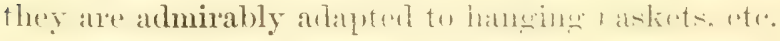

\section{Caladiums.}

Cetulonian. Tessermine.

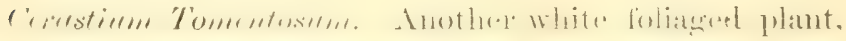
with small, narow leares. well suiterl. for hanging haskets or stands.

Centrened Comdide, a valuable plant to contrast with

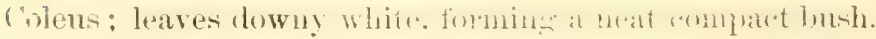

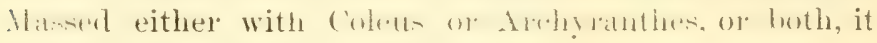
prolures a most pleasing effect.

rississ Amazonice.

C'issus Discolor. 


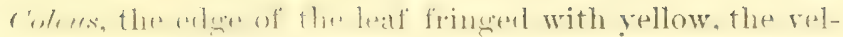
rety gromud is dark maroon.

Cotoms, fure plants, suitable for baskets.

Gereminm Zomele, Bicolon.

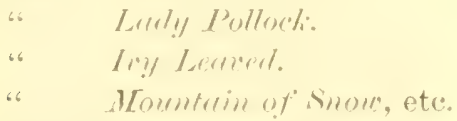

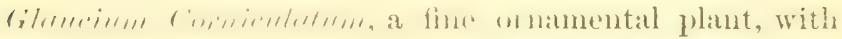

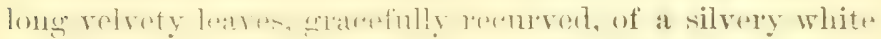

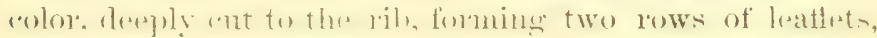
each of which is again deeply cut and curled.

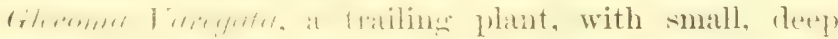

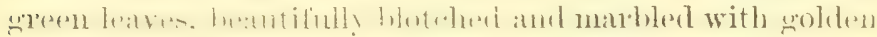

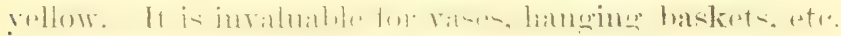

llibiseres comperii.

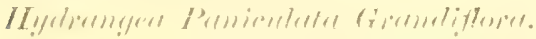

Inies.

Perillo, this heantiful follagerel plant is of a deepe mul-

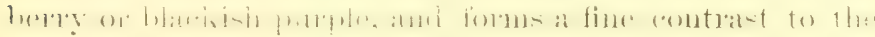

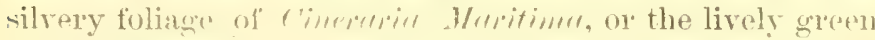
of other plants. I varisty of this plant is vatiegated and

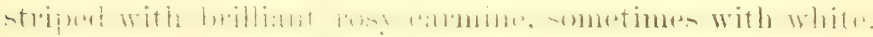
producing a chasmine effect.

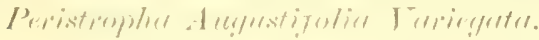

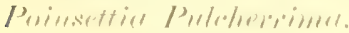

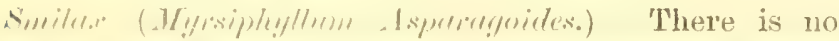
rembing phat in endtiontion that sulpasses this in the

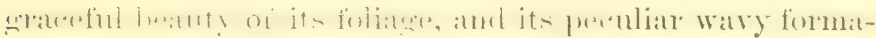

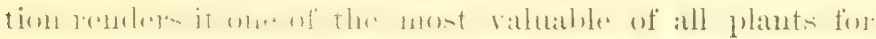

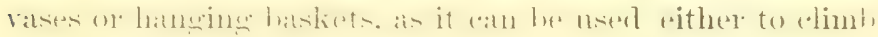
or to droop, as repmired. 



$$
\text { PART II }
$$




\section{CO.VTENTS OK PART II.}

Introduction to Palt II....................................... 21

('hapter I, Analysis of Ieatre-................................ 23

. II, Flowerless Plants and Fall of the Leaves............ 27

.. III. Mitmuer of 'liking Imprestions of Leaves............ 29

Price List of Materials........................................... 31 


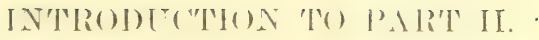

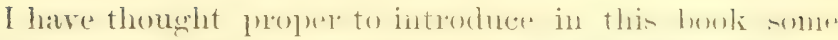

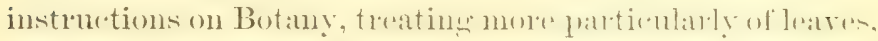

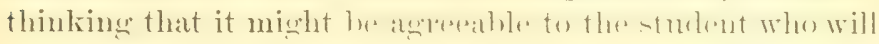

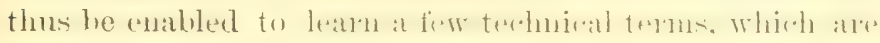
so extensively used in that sciencer.

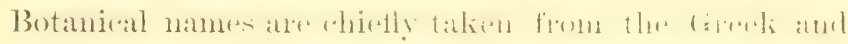

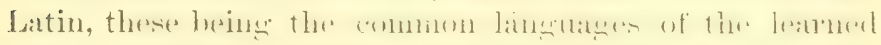

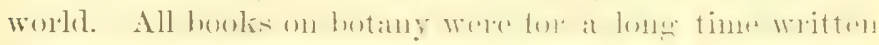
in Latin: the origninal works of linmaren ane in that lat1-

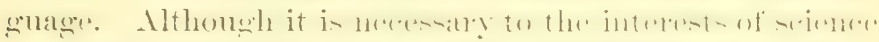

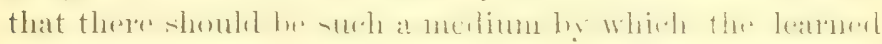

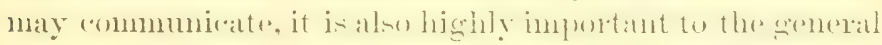
impurovement and happlume af mamkind that theip tis-

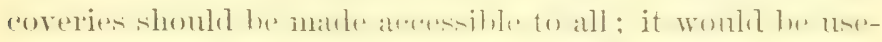
less to attrempt to divent hotany of all its terohnionel terms

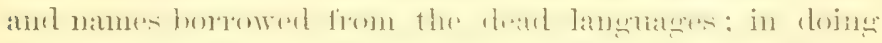

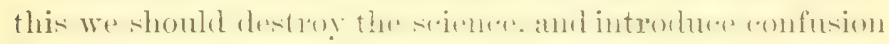

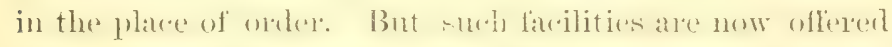

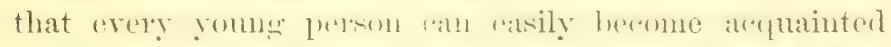

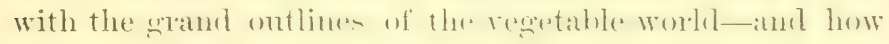

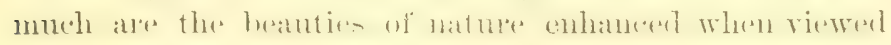

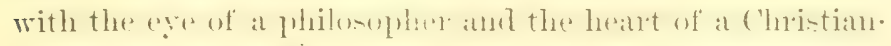

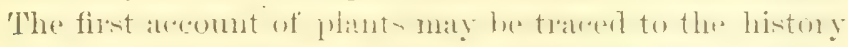

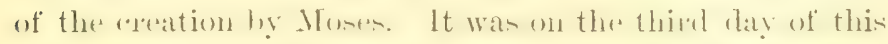

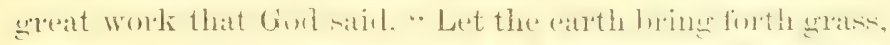

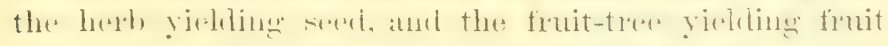

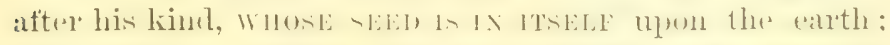
and it was so ; and the oath bromerint forth grass, and the herb yielding seed atter his kind, and the tree yielding 
fruit, whose seed was in itself, after his kind; and (ioi)

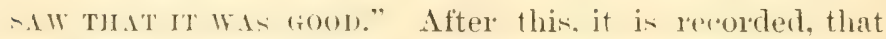
fod gave to ddam every herb and rvery ThEs BEAnIso FRLIT: the latter wan for him exclusively, but to the beasts of the earth and the lowls of the atr. and to "rery thing

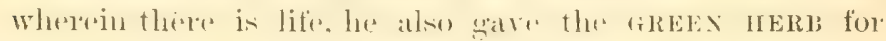
meat. Silans anderting to Moly seripture, gave names to all the hatat of the firhl and the fowls of the air : ancl Milton inagine that Eve was assigned the pleatsunt task of eriving names to flowers, and nmmbering the triber of plants. When our first parents, as a punishnent for their disoberirnce, are about to leave their delightful Eden, Eve. in the linneruage of the proet, with hitter regret "xclains:

" Must I thus leave thee. Paradise?

$\because * * * \quad *$ Oh towers

That never will in other climate grow.

** Which i hred up with tender hamd.

firm the firt opening bud, and gave ye nemes;

Who now thatl rear ye to the sun. or rank

Yom tribes"?" 


\section{(HAPTHR)}

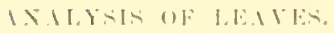

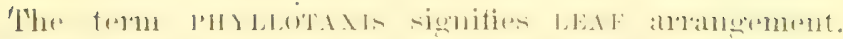

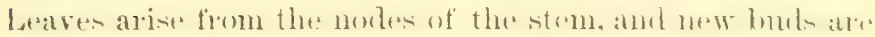

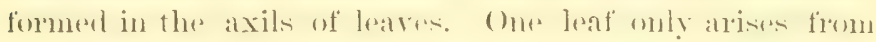

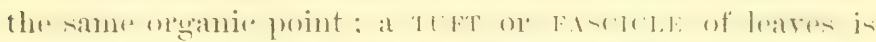

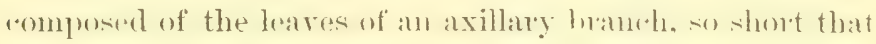

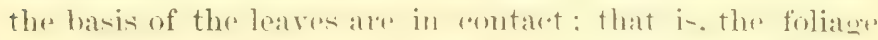
develoge without any alomeation of the axis on the inter-

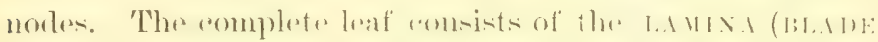

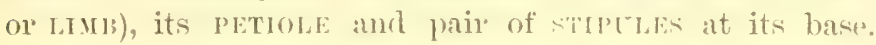

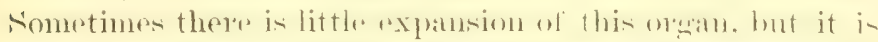

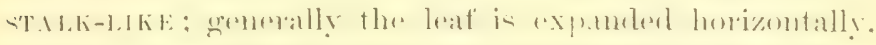

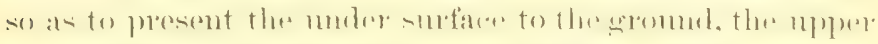

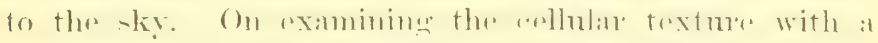

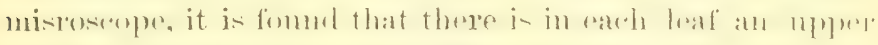

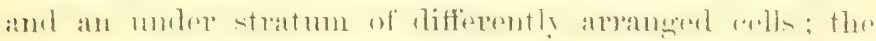

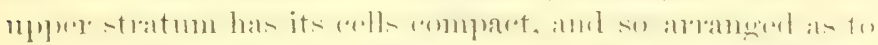

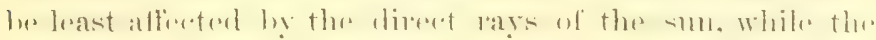

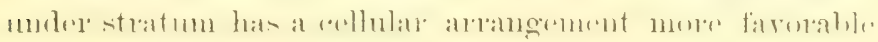
for "rappostion or exhalation.

Loaves aro furdished with poles ealled sToy.1T. for "x-

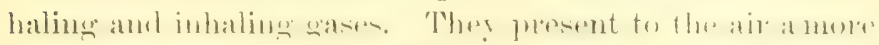

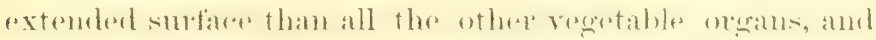
ale of enent importanew to the vitalit! of the nlant. hy imlibing saitable nomrishment, and thoow

* The second part has, to a great extent, been copied from a valuable book by oue of our be $t$ botanists. 
as would be useless or injurions. In other words, leaves are olgans of DIGESTION and RESPIRITION.

'The new plant is allont a rorrox : in its simplest form it consinte of two leares atul a hut, which is the axis, and forme the -tom and rout. SElisir. loaves first apleat above the surfine of th: wath, at in the garden bean : these loares are the cotyledonis, which, after nom-

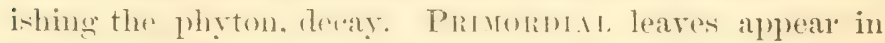
the axils of the smominal leates, and resemble them in position, form :mu sizr. 'The primordial leaf, aceoreling to the fanciful irloa of a Fomeh lortanist, is a sketroh which Nature makes before the perfection of here work. Curde-

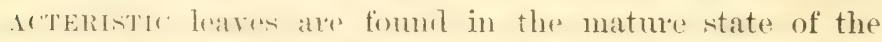

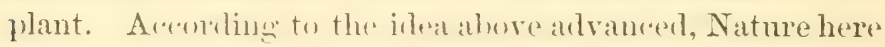
perefects her design. It is not always, howerer, that this plocess, with remall to chances of leatres, takes place; as

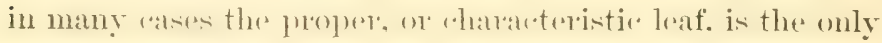
one which appears.

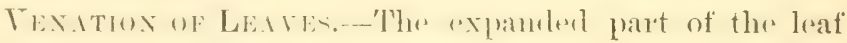
is rallerl the ray

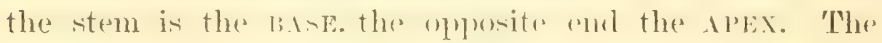

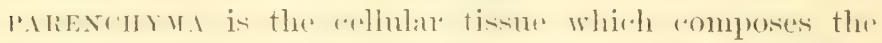
hody of the leat, or the filling of a frame-work or skeleton

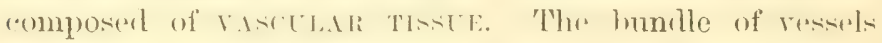
which rompose this frame-wotk ate ralled versis, some-

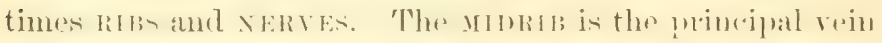

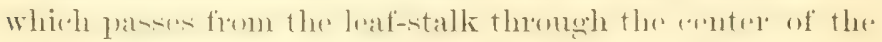

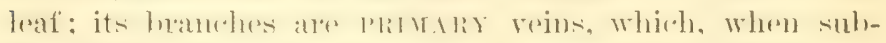

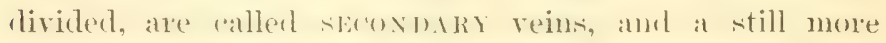
minute division, veinlets, The distribution of reins in the

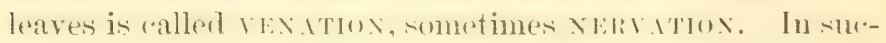
rulent plants the veins are sometimes olseme: they are

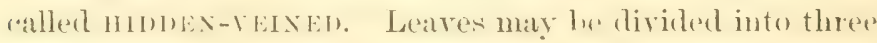

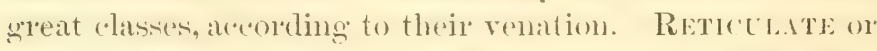
verren leaves, in which the petiole is probunged into the 
Jeaf in the corm of the mirleih, and there is an angular network of resiels, as ocemrs in the leaves of exogenous plants. as the oak, rose, etr. P'llit.1:1-TExal, in which the veins rum in a straight or "urvert manner from hase to apex, or from the midrih to the marerin of the leat, and ar\% (ommereted by simple transwerse veins, as appears in most endogenoms or monocotyledomoms plants, as the lily, grasses, ote. ForkEn-rEs ly forked divisions, which do not agrain unite, as in the ryptogamoms plantr, of which the fern is an "xample. RETH'T.ATE-YEIXEU leaves are divided into the lEATHER-

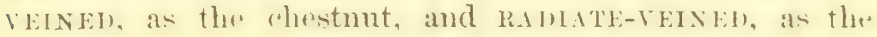
maple.

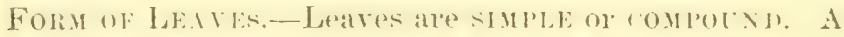
simple leaf is when the lamina consists of sereral parts. "arh of which is attionlated with the rommon petiole, at the same manner as the latter is connected with the stem.

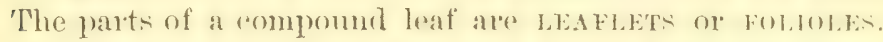
'The shape and ontline of leares are found to depend rhiedly nfon the arrangement of the frame-work or vaseular portion. 'The form of leaves is prperesert hy terms horrowed

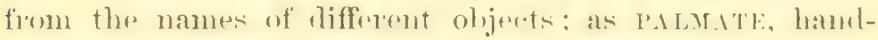

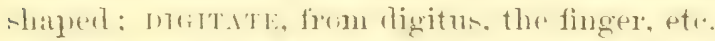

Leaves vary in MArist

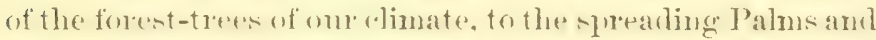
Bananas of the torril zome. As we alpurade the torrid zone the leaves increase in magnitude.

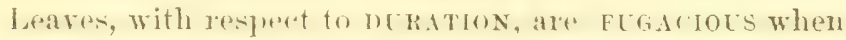
they fall arly, or soon after their first appearance. DECInots, falling at the commencement of winter: this is the ase with the leaves of most jiants, ac far as 30 or for from the equator.

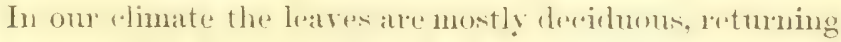
in atumm to their oricrinal dust, and enrivhing the soil from which they had derived their nourishuent. In the 
regions of the torrid zone, the leaves are mostly persistent and evergreen; they seldom fade or decay in less than six year's, but the same trees, removed to our climate, sometimes become annual plants, losing their foliage every year.

'The cikEEx coLoti of leaves is owing to a coloring mat-

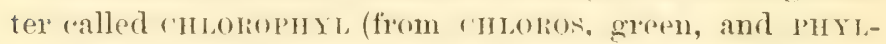
1.0x. leat), which floats in minute grobules in the fluid of rells, acempanierd by stareh grains. The green color be("omes lighter or deepex, acomding to the quantity of chlorophyl and the agregegation of cells. Leaves have not that milliancy of color which is seen in the corolla or blossom: but the heanty of the corolia has only a transient existence, while the less showy leaf remains fresh and verlant after the flower has withered away. The substance of most leaves is so constituted as to abools all the rays of light

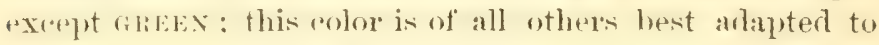
the extreme sensibility of our orgams of sight. 'Thus, in evident areommolation to wur sense of visions, the ordinary dress of nature is the only "olor upon which our eyes, for any length of time, ean rest without pain. But although green is almost the only rolor which leaves retfect, the variety of its hatles is almost innumerable. 


\section{CHAP'LER II.}

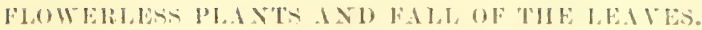

Arlioisolis, Flowerless Plants ane propagated by spores instead of seeds; these have a DIsther Axis grow-

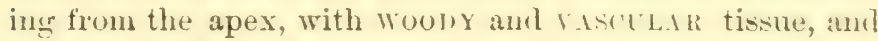

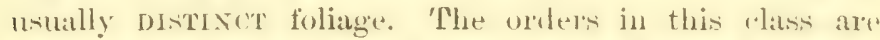

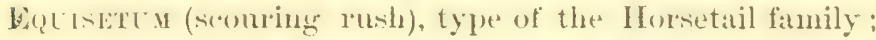
the firm, the type of the order Fuldes, dividerl into many sult-orders: ground-pine or club-moss. the type of the order Lycopodiacex.

The Fald. of THE Ltad has bern thus axplained: When the leaf and stem atre both in a hesalthy state, the base of the former and the banch that bears it, both increase at the same rate, but after the decaly of the leaf, its hase carl no louger adapt itself to the growing branch, which is constantly increasing in diameter by the formation of the new wook. There is, ronsequently, a ruptures of the connecting vessels, the leaf is disjointed at the base, (1) artirulation, and falls off. ats a dead part of a living animal is cant off. Endogenous stems do not increase in diameter, therefore their leaves deary, but do not commonly fall; they remain on the stem.

The rich antmunal sienery of American forests is regarched by the European traveler with astonishment and delight, as fal exceeding anything of the kiml which the old world presents.

Painters, who have attempted to imitate the splendid hnes of our forests, hare, by foreigners, been atcrised of 
exaggeration; hut no gorgenus coloning of art can exceed the bright scarlet, the deep crimson, the rich yellow, and the dark brown, which these scenes present.

The stuclent who has learned something of the anatomy and physiology of leaves, will he incheod to pay attention to them in their different stages, from their situation in the bad to their full arowth and perfection-will feel a new interest in their rhange of color, when the philosophy of this rhange is understond: even the dry skeletons of leaver, which the bhasts of Iutumu strew around as, may not only afford a direct moral lesson, as emblematic of our "wn mortality, hut, in exanining their structure, we ares led to armile and atore the power which formed them."

\footnotetext{
* Carbonic acid gas is the fork of flants; this consists of carbon and oxygen, and decomposed by the ageney of light; the carbon becomes incorporated with the veretable, forming the basis of it substanes, while the oxysen is exhaled, or thrown off into the atmosphere.
} 


\section{CHAPTER III.}

MANNEIR OF TAKING IMPRESSIONS OF LEAYES.

Hold wiles patper in the smoke of at lamp of of piteh, un-

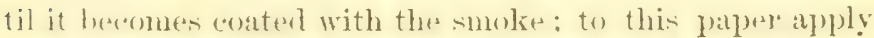
the leat of which vou wish an impression, having meri-

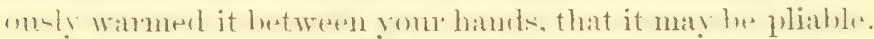
Plate the lower surface of the leat' upon the hlarkened-lurfiler of the oil-patper, that the numeroms voins, whith atw $\therefore$ ) prominent on this side, may receire from the palere at portion of the monolis. Lay a paper over the leaf, am thrn press it gently $140 m$ the smokesl paper with the fingers, or

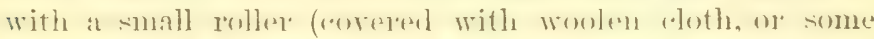
-imilat! weft material), so that every part of the leat mat!

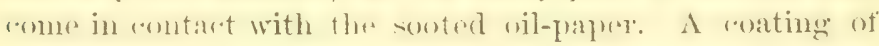
the smoke will artheres to the leat. 'Theru resuoses the leat

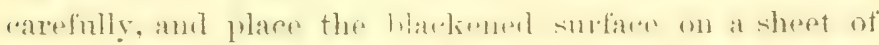

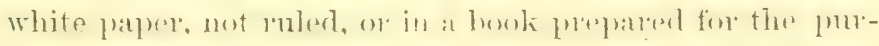

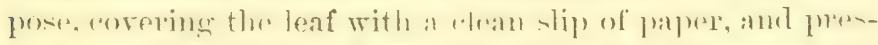
-ing npon it with the fingers, or loller. an lofore. 'Thm-

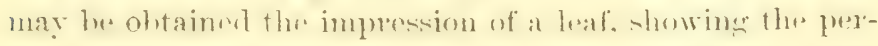

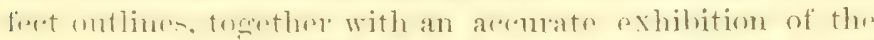
reine which axtent in erery direstion through it, more

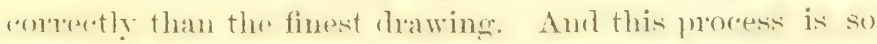
simples, and the material io easily obtainesl, that any person, with a little prartice to enakle him to aplely the right quantity of smoke to the oil-palpere and give the leat a 
proper pressure, ran prepare beantiful leaf impressions, such as a naturalist would be proud to possess. There is another, and we think a better method of taking La: l: mpressioxs than the precelling one. The only differenc* in the process consists in the use of PRINTST INK instear of smoked oil-paper. 


\section{PRICE LIST OF MATERIALS.}

A Lamp, with two burners,
1 Pound Cake Wax,
1 -

‥B. 'The ahove list of materials is what is indispensable? to each stulent for lasming "Foliage." All those articles sent to any part of Ameriora, and may be paid on delivery. thus saving all trouble.

Order's promptly attended to.

Wax materials always on hand. 


\section{WA A}

The heantiful art of Wax Flower Making, which has bren tancht so successfully in New lork in three hours'

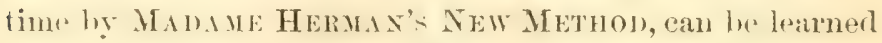
now for only s2.50, by buying her new Book of Instruction, with many Practiral Plates, and an Entire Set of Monlus being incluted in the price. This hook has been romposed to supply the want of per'sons living out of New Jork, and who "amnot "ome to this city to learn the methor.

Any on. with the "love of the heantiful" "aunot hut almire well made Wax flowex's which resemble nature so well that many persoms ane daily deceived by them, taking them for natural flowers: they are well adapted for decorative purposes, and nothing is more pretty for pressents than Wax Flowers.

The Flowers taught by this book are:

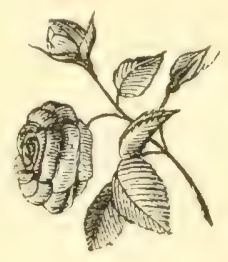

The Rose and Bud.

'The Pond or Water Lily \& Bud 'I'he Lily of the Valley.

The Morning Glory,

The T)ark ('love (arnation.
'The Tuberose.

The White Cameli:t.

The Fusehia.

The Sweet Pea.

The Green and Autumu Lave-

'To reach all "laswer, this hook is sold for only 8.5n), in'luding a Full Set of Moulds, which would cost to manufacture, over one hundred dollars.

Agents wanter in every City and 'Town in America. 


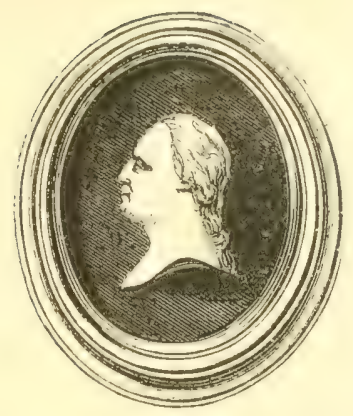

\section{A Beautiful Portrait of Washington in Wax.}

Taken from a painting perented hy trenelal Washington to a member of the celelorated ('hew family, of great renown (of trelmantown, Pa.), in a hamdsomm oral flatme. 11

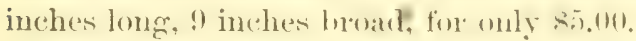

Sent to any part of the Tnited States, and naty he paid on delivery, thus saving all tromble. (Orders formutly attended to.

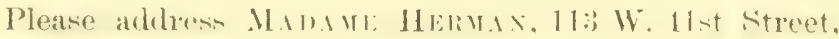
New York. 


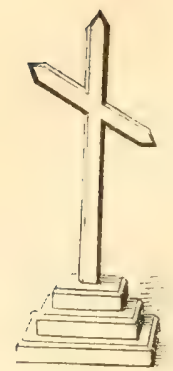

\section{THE AMERICAN CROSS.}

'This beantiful Cross which is an imitation of Parian Marble, and which will last, with a little care, a life-time, and is ten inches high, is sold for only $\$ 1.50$. 


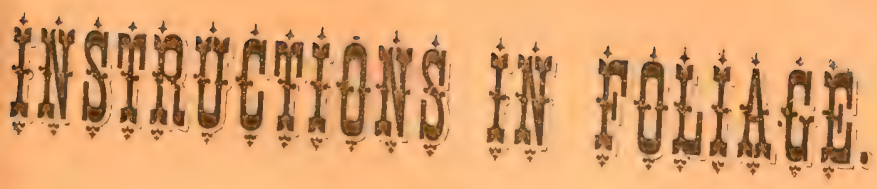

TY

\section{MADAME HERTIAN,}

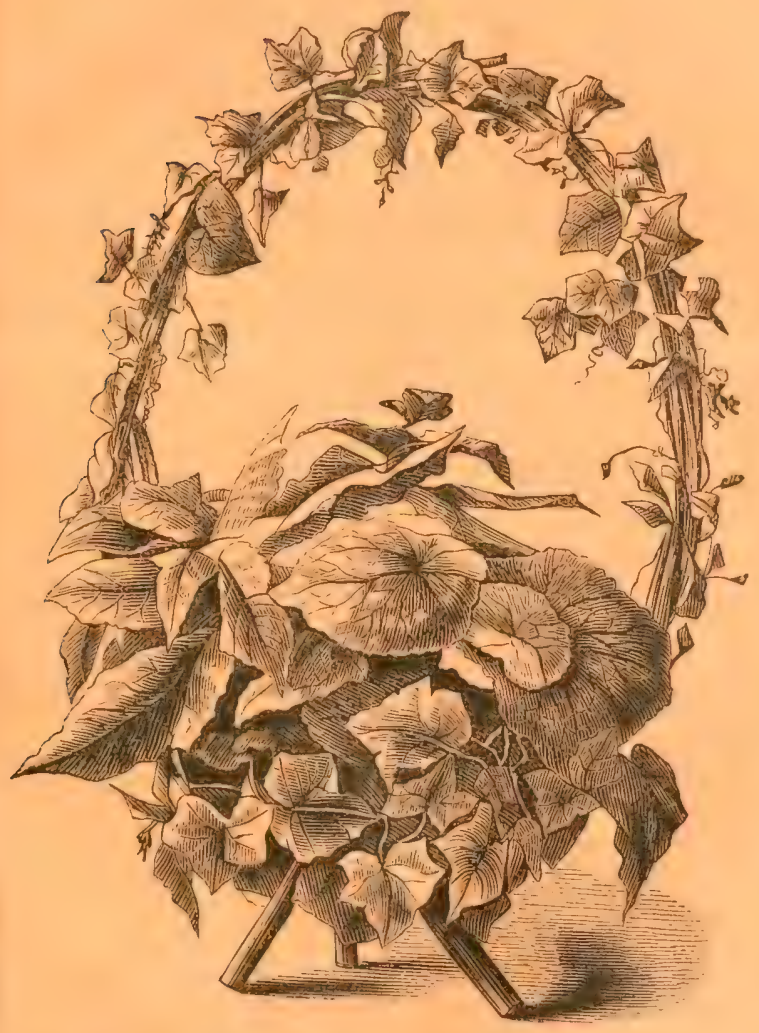

3 WEST FORTY.FIRST ST., NEW TORI

Price, $\$ 3.00$. 




\title{
THE BOOK OF INSTRUCTIONS
}

\author{
IN MY NEW METHOD OF
}

\section{MAKING WAX ELOWERS,} WITH AN ENTIRE SET OF MOULDS,

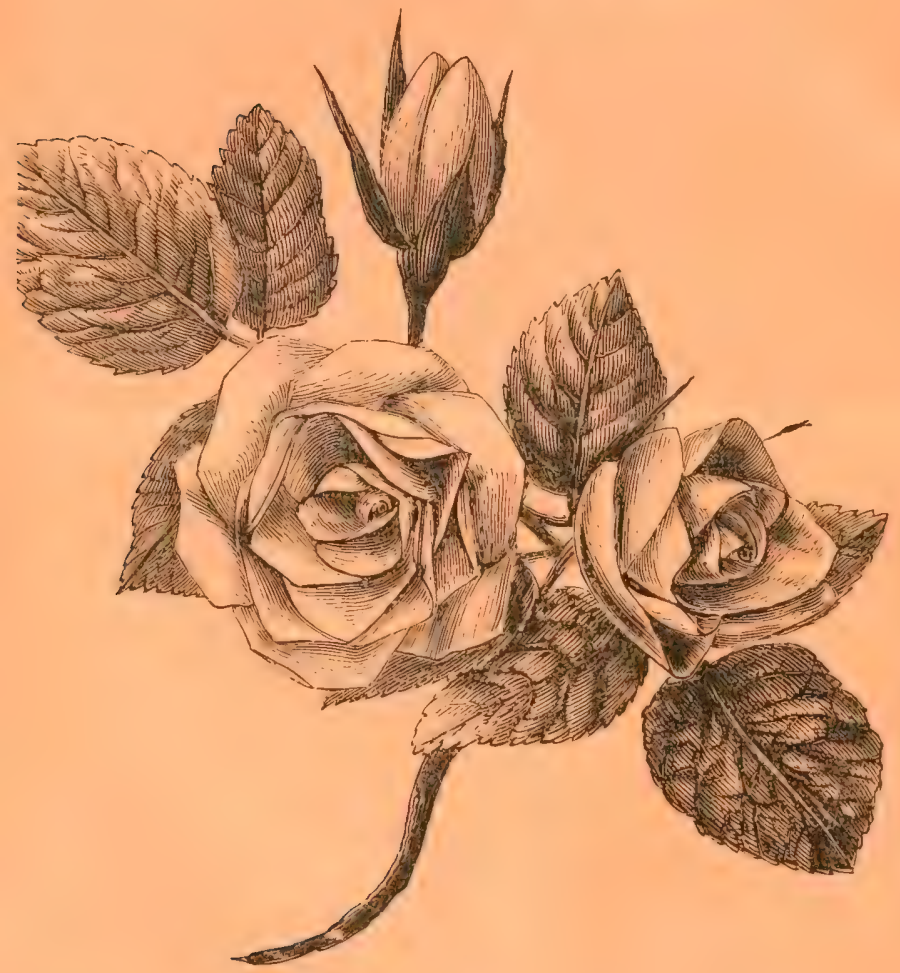

$$
\text { PRICE, \$2.50. }
$$

Agents wanted in every city and town in America.

PLEASE ADDRESS

ADAME HERMAN, 113 West 41st Sireet, New York. 






Chon

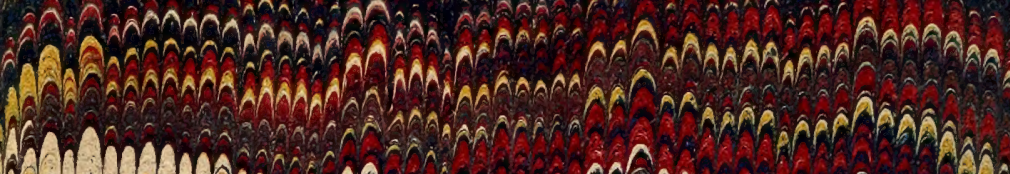
Dimina (1)

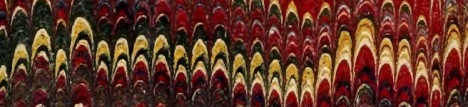
(6)

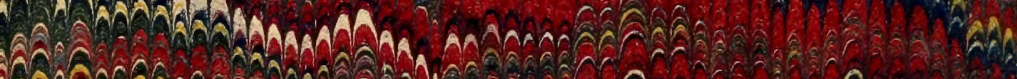
AMAn man 2NAN किसि

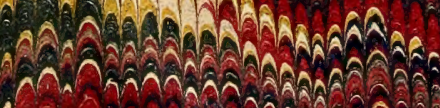
Ham

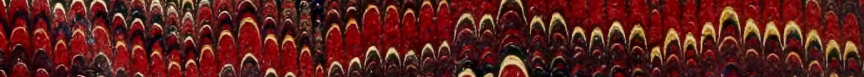

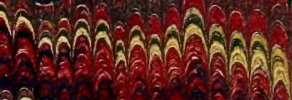
ÂA M

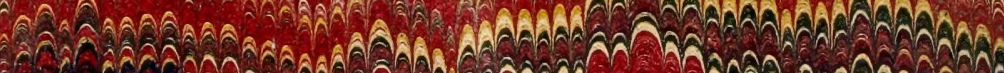
a 1.1.

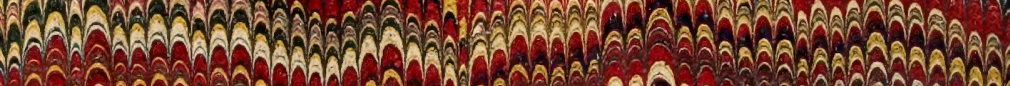

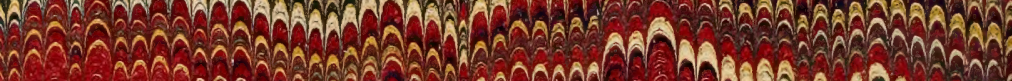


MMA $A$

AMA

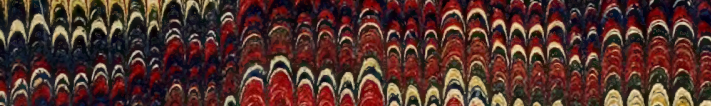

an (1) mman muMnAm D A

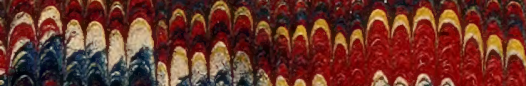

M MMM MACAAHA

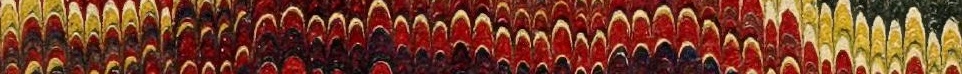

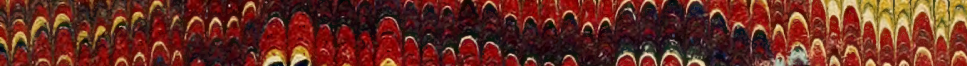
anchn 1. anan mWMAHA A A monn

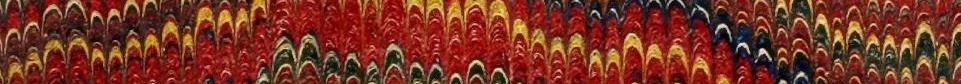


LIBRARY OF CONGRESS

|||||||||||||||||||||| 00141480807 . 